\title{
Influence of jack bean (Canavalia ensiformis (L) DC) milk processing on bioactive compounds and its antioxidant activity
}

\author{
Anita Maya SUTEDJA ${ }^{1,2,3 *}$ (D), Ayumi ITO ${ }^{4}$, Emiko YANASE $^{1 *}$, Irmanida BATUBARA ${ }^{5,6}$, Dedi FARDIAZ ${ }^{2}$, \\ Hanifah Nuryani LIOE ${ }^{2}$
}

\begin{abstract}
To seek a possibility of jack bean (Canavalia ensiformis (L) DC) utilized as a food, the development of jack bean milk processing was investigated. The processing steps included boiling, soaking, grinding and heating. The raw beans, boiled beans, soaked beans, extracted liquid and separated solid were all freeze dried. Those samples were evaluated for total phenolic content (TPC), total flavonoid content (TFC), and DPPH free radical scavenging activity, compared to those of the raw materials. The increase in TPC and TFC during bean boiling observed, and estimated due to the liberation of phenolics by the destruction of chemical bonds in cell matrix, physical destruction of the matrix by heat treatment observed by SEM results reported in this study. This mentioned that some phenolics existed as a bonded component. Decreasing of TFC was observed in the soaking step due to the migration of the compounds into soaking water. UHPLC-MS-MS based multivariate analysis showed grouping of phenolic compounds present in methanol extracts of the dried samples, mentioning its changes during processing. Kaempferol glucosides detected and quantified in this study, play an important role in the changes. The considerable concentrations of them in jack bean milk, lead to the development of functional drink.
\end{abstract}

Keywords: antioxidant; jack bean milk; bean milk processing; flavonoid; kaempferol glycoside.

Practical Application: Bioactive compounds and its antioxidant activity support the jack bean milk as a promising functional food.

\section{Introduction}

Jack bean (Canavalia ensiformis (L) DC), a kind of legume consumed in some countries, but has rarely processed into food products. Given that the beans contained proteins at 20-30\% (dry basis) (Ade-Omowaye et al., 2015; Doss et al., 2011), the beans have a potency to be processed into a plant-based milk product. Moreover, several studies have shown flavonoids contained in this bean (Olugboyega \& Edem, 2018). Therefore, there are various health benefits, including antioxidants and anti-diabetes that have been reported (Ade-Omowaye et al., 2015; Vadivel et al., 2012; Sowndhararajan et al., 2011). To date, the milk processing from the beans as well as the phenolics occurrence in the bean milk have not been investigated yet.

Jack bean milk could become a new variation in non-dairy milk products, this product variety also known as plant-based milk. If it is developed, it can be an alternative product for consumers who suffer from lactose intolerance and animal milk allergies, as well as those who have a vegetarian lifestyle. The product is a type of fluid extract obtained from parts of plants that are crushed and ground with water, and then its liquid part simply separated from solid (Sethi et al., 2016; Tangyu et al., 2019). However, the jack bean milk product can be made by mimicking the soy milk processing with the general process stages of soaking and heat grinding of soybeans. Some modifications need to be made to produce the jack bean milk products with characteristics similar to animal milk. The physical characteristics of raw Jack beans are the hard seed structure and the thick peel, so that the rate of water absorption is lower than soybean when in soaking process. Therefore, to make the jack beans milk, several additional steps were needed in order to obtain jack bean milk that resembles soybean milk.

On the other hand, phenolic compounds are known to be sensitive by heat treatment even in a short period of cooking (Al-Juhaimi et al., 2018) and highly susceptible to degradation (Bakowska et al., 2003; Volf et al., 2014). This is similar to what happened to soy, that the isoflavone content reduced during the soymilk manufacturing process (Huang et al., 2006; Zhang et al., 2015), depend on the variations in the processing methods (Niyibituronsa et al., 2018). The decrease of bioactive compounds leads to the decrease of antioxidant activity. The variations in the bean milk processing includes boiling, soaking sand hot grinding process. Each processing step has a potency to cause changes in the components contained in the beans and their extracted liquid,

${ }^{1}$ Faculty of Applied Biological Sciences, Graduate School of Applied Biological Sciences, Gifu University - GU, Gifu City, Japan

${ }^{2}$ Department of Food Science and Technology, Faculty of Agricultural Engineering and Technology, IPB University, IPB Campus Darmaga, Bogor, West Java, Indonesia

${ }^{3}$ Department of Food Technology, Faculty of Agricultural Technology, Widya Mandala Surabaya Catholic University - WMSCU, Surabaya, Indonesia

${ }^{4}$ Graduate School of Natural Science and Technology, Gifu University, Gifu City, Japan

${ }^{5}$ Department of Chemistry, Faculty of Mathematics and Natural Science, IPB University, IPB Campus Darmaga Bogor, West Java, Indonesia

${ }^{6}$ Tropical Biopharmaca Research Center, IPB University, IPB Campus Taman Kencana Bogor, Indonesia

${ }^{*}$ Corresponding author: e-yanase@gifu-u.ac.jp; maya@ukwms.ac.id 
including the bioactive compounds, due to oxidation or hydrolysis reactions. The aim of this study was evaluating each jack bean milk processing step to the changes of bioactive components in order to establish an appropriate milk processing method of this bean.

\section{Materials and methods}

\subsection{Materials}

Jack beans (C. ensiformis (L) DC) were purchased from a local farmer located in Temanggung, Central Java, Indonesia. Sortation and separation for the broken, molded, sprouted, and damaged beans were conducted at laboratory, then the raw beans stored at $-30{ }^{\circ} \mathrm{C}$ prior to processing and analysis.

\subsection{Jack bean milk preparation}

The process of jack bean milk was performed in four main steps as outlined below (Figure S1). Jack beans $(50 \mathrm{~g})$ were boiled $\left(95^{\circ} \mathrm{C}\right)$ in water $(500 \mathrm{~mL}$ ) for $30 \mathrm{~min}$ (step 1). After drained, the beans were soaked in water $(250 \mathrm{~mL})$ for 24 hours at room temperature with the soaking water replaced every 12 hours then re-drained (step 2 ). Beans that have been peeled, washed with running water and re-soaked in water $(250 \mathrm{~mL})$ at room temperature for $50 \mathrm{~min}$, then re-drained (step 3). The beans were then ground using soymilk maker (Fukuno Sangyo Co., Ltd., China) to obtain jack bean milk. The milk was filtered manually by double layer of filter cloth, and the separated pulp was also collected for further analysis (step 4) (Method A). Method B is the same as method A except that the step 3 is omitted. Method C is the same as method B except that the step 2 is performed for 12 hours. All samples were freeze dried $\left(-90^{\circ} \mathrm{C}, 3 \mathrm{~Pa}\right)$ using a freeze dryer (Eyela FDU-2200). After the freeze drying, the raw (R), boiling (B30), soaking I (S12 and S24), soaking II (SS), milk (MLA, MLB, and MLC) and pulp (MSA, $\mathrm{MSB}$, and MSC) samples were ground and sieved using a sieve (100 mesh size). All dried samples were stored in $-30^{\circ} \mathrm{C}$ until further use. The yields of samples based on $50 \mathrm{~g}$ dried beans $(\mathrm{R})$ were as follows: B30 (48.5 g), S12 (46.0 g), S24 (41.6 g), SS (40.9 g), MLA (16.8 g), MSA (22.2 g), MLB (20.3 g), MSB (17.0 g), MLC $(19.3 \mathrm{~g})$ and MSC (16.8 g).

\subsection{Dried sample extraction}

Dried samples were extracted with the same volume of methanol (1:10 w/v) based on the weight of dried raw beans $(50 \mathrm{~g})$. Extraction was performed in room temperature for 3 hours and the extracted liquid was separated using a centrifuge (Kubota 3700, Japan) at $5000 \times \mathrm{g}$ for $15 \mathrm{~min}$. The methanol extracts were stored in $-30^{\circ} \mathrm{C}$ prior to analysis. For UPLC-MS-MS, the methanol extracts were added with sulfisoxazole $(1 \mathrm{pg} / \mathrm{mL}$ extract $)$ as the internal standard. All extracts were prepared in triplicate and analyzed for total phenolic content (TPC), total flavonoid content (TFC), antioxidant activity (DPPH free radical scavenging activity), kaempferol glycoside concentration and UPLC-MS-MS profiles.

\subsection{Total Phenolic Content (TPC), Total Flavonoid Content (TFC) and DPPH scavenging activity}

Folin-Ciocalteu assay was used for determination of total phenolic content (TPC) according to our previous study (Sutedja et al., 2020a) and was expressed as mg gallic acid equivalents (GAE) per g sample. Total flavonoid content (TFC) was determined using a colorimetric as performed in our previous study and was expressed as mg catechin equivalents (CE) per g sample. DPPH free radical scavenging activity method was used to expressed the antioxidant activity (Sutedja et al., 2020a). All samples were evaporated using centrifugal separator (CVE-3100, Eyela, Japan) to dry and then dissolved in $25 \mu \mathrm{L}$ of methanol before analysis.

\subsection{Ultra-high-performance liquid chromatography-time-of- flight mass spectrometry (UHPLC-TOF-MS) analysis}

UHPLC system coupled to a QTOF-MS (Waters Xevo G2 QTOF, Waters, USA) was used for performing the analysis. The QTOF-MS was operated with electrospray ionisation (ESI) at the mass resolution of 20,000 and controlled by MassLynx 4.1 software. The collision energy (CE) of the experiments was $6 \mathrm{~V}$ and the source parameters were set as follows: capillary $2.5 \mathrm{kV}$, sampling cone $30 \mathrm{~V}$, extraction cone $4 \mathrm{~V}$, source temperature $150{ }^{\circ} \mathrm{C}$, desolvation temperature $500{ }^{\circ} \mathrm{C}$, desolvation gas flow $1000 \mathrm{~L} / \mathrm{h}$, and cone gas flow $50 \mathrm{~L} / \mathrm{h}$. Solution of $0.5 \mathrm{mM}$ sodium formate was used as calibration of the mass spectrometer. Leucine Enkephalin $(2 \mu \mathrm{g} / \mathrm{mL}, \mathrm{m} / \mathrm{z} 556.2771$ in positive mode) was used as lock spray at a flow rate of $10 \mu \mathrm{L} / \mathrm{min}$. An Acquity UHPLC BEH C18 column $(2.1 \mathrm{~mm}$ I.D. $\times 100 \mathrm{~mm}, 1.7 \mu \mathrm{m}$, Waters, USA) was used for chromatographic separation and set at $35^{\circ} \mathrm{C}$. A sample $(1 \mu \mathrm{L})$ was injected using an auto sampler. The mobile phases at a flow rate of $0.4 \mathrm{~mL} / \mathrm{min}$ were combination of $1 \%$ formic acid in water (A) and methanol (B) with gradient condition as follow: $5 \% \mathrm{~B}$ as initial, $15 \% \mathrm{~B}$ at $8 \mathrm{~min}, 25 \% \mathrm{~B}$ at $11 \mathrm{~min}, 32 \% \mathrm{~B}$ at $13 \mathrm{~min}, 40 \% \mathrm{~B}$ at $20 \mathrm{~min}, 55 \% \mathrm{~B}$ at $26 \mathrm{~min}, 95 \% \mathrm{~B}$ at $32 \mathrm{~min}$ and kept it for $2 \mathrm{~min}$. Standards of kaempferol glycosides were purchased from Tokyo Chemical Industry (Japan) and used for identification and quantification using calibration curves.

\subsection{Scanning Electron Microscope (SEM) analysis}

Scanning electron microscope analysis was performed through cross section of whole bean and flour samples. Conductive treatment was carried out using 1-buthyl-3-methylimidazolium tetrafluoroborate or ethyl (2-hydroxyethyl) dimethylammonium ethyl sulfonate) liquids though the cross section of the bean. All samples were coated with approximately $10 \mathrm{~nm}$ osmium tetroxide using a Neo Osmium Coater (NEOC) model Neoc-ST (Meiwafosis, Co., LTD, Tokyo, Japan), and were examined using a scanning electron microscope (model S-4300, Hitachi High Technologies, Tokyo, Japan) at a voltage of $1 \mathrm{kV}$.

\subsection{Quantitative kaempferol glycoside analysis}

Each sample $(20 \mu \mathrm{L})$ were injected into a reverse-phase HPLC-PDA system consisted of Jasco PU2089 intelligent pump equipped with a JASCO MD-2010 plus detector and a Jasco CO-2065 Plus column oven (Tokyo, Japan). The analysis used reversed phase column (Cosmosil 5C18-MS-II, 4.6 ID $\times$ $150 \mathrm{~mm}$, particle size of $5 \mu \mathrm{m}$ ) and controlled the temperature $35^{\circ} \mathrm{C}$. The mobile phase comprised $0.5 \% \mathrm{HCOOH}$ in $\mathrm{H} 2 \mathrm{O}$ (A) and $0.5 \% \mathrm{HCOOH}$ in acetonitrile (B), and the following gradient was used: initial $10 \% \mathrm{~B}$ for $10 \mathrm{~min}, 15 \% \mathrm{~B}$ at $30 \mathrm{~min}$, 
$25 \% \mathrm{~B}$ at $45 \mathrm{~min}, 35 \% \mathrm{~B}$ at $55 \mathrm{~min}, 45 \% \mathrm{~B}$ at $60 \mathrm{~min}$, and $55 \%$ $\mathrm{B}$ at $70 \mathrm{~min}$. The flow rate was set to $1 \mathrm{~mL} / \mathrm{min}$. Detection was performed at $330 \mathrm{~nm}$ corresponds to the absorbance of the flavonol backbone. Quantification was performed using the area under each peak determined by ChromNAV software (JASCO, Tokyo, Japan). Determination of each compound based on retention time data from the previous study (Sutedja, et al., 2020b) and quantified using the standard curve of kaempferol. Kaempferol compounds diluted in methanol with concentrations of $5 \times 10^{-4}, 1 \times 10^{-3}, 5 \times 10^{-3}, 0.01,0.05,0.1$, 0.5 and $1 \mathrm{mg} / \mathrm{mL}$ were used as standards and calculated based on the molecular weight. The content of each compound was expressed as $\mu \mathrm{g} / \mathrm{mL}$ extract.

\subsection{Data analysis}

All data obtained were statistically analysed using analysis of variance (ANOVA) and the Tukey's post hoc test $(p<0.05)$ performed in Past 4.0 software (Oslo, Norway) (Hammer et al., 2001). UPLC-MS dataset was processed using MassLynx 4.1 (Waters) software to prepare the marker table of features. Interval retention time of total ion chromatogram (TIC) was set from 1 to 27 minutes, mass tolerance was 0.05 , peak with at $5 \%$ height was 20 seconds and peak-to-peak baseline noise was 150 . Intensity threshold, mass window and retention time window for data collection were set as 50 counts, 0.1 and 1.0. The multivariate analysis of Partial Least Squares-Discriminant Analysis (PLS-DA) performed using Metaboanalyst online platform (Chong et al., 2019). The raw data was firstly normalized with the concentration of internal standard substance of sulfisoxazole and then all the data was transformed by log transformation and scaled by pareto scaling. Important features were determined as variable influence on projection (VIP) which bigger than 1 .

\section{Results and discussion}

\subsection{Changes of TPC, TFC and antioxidant activity during jack bean milk processing}

Manufacture of jack bean milk by method A involved several processing steps that changed the composition of several compounds from its original raw bean (R). Starch and protein contained in this bean will be gelatinized and hydrolyzed during heating (boiling, stage 2) and grinding (step 4). In addition, bioactive compounds, mainly as phenolics, also undergo changes as evaluated through TPC and TFC (Figure 1).

TPC was significantly increased $(p<0.05)$ after boiling while reduced in the following steps (Figure 1a), while TFC was non-significantly increased as boiling and soaking applied (Figure 1b). It was presumed that was due to the heat that
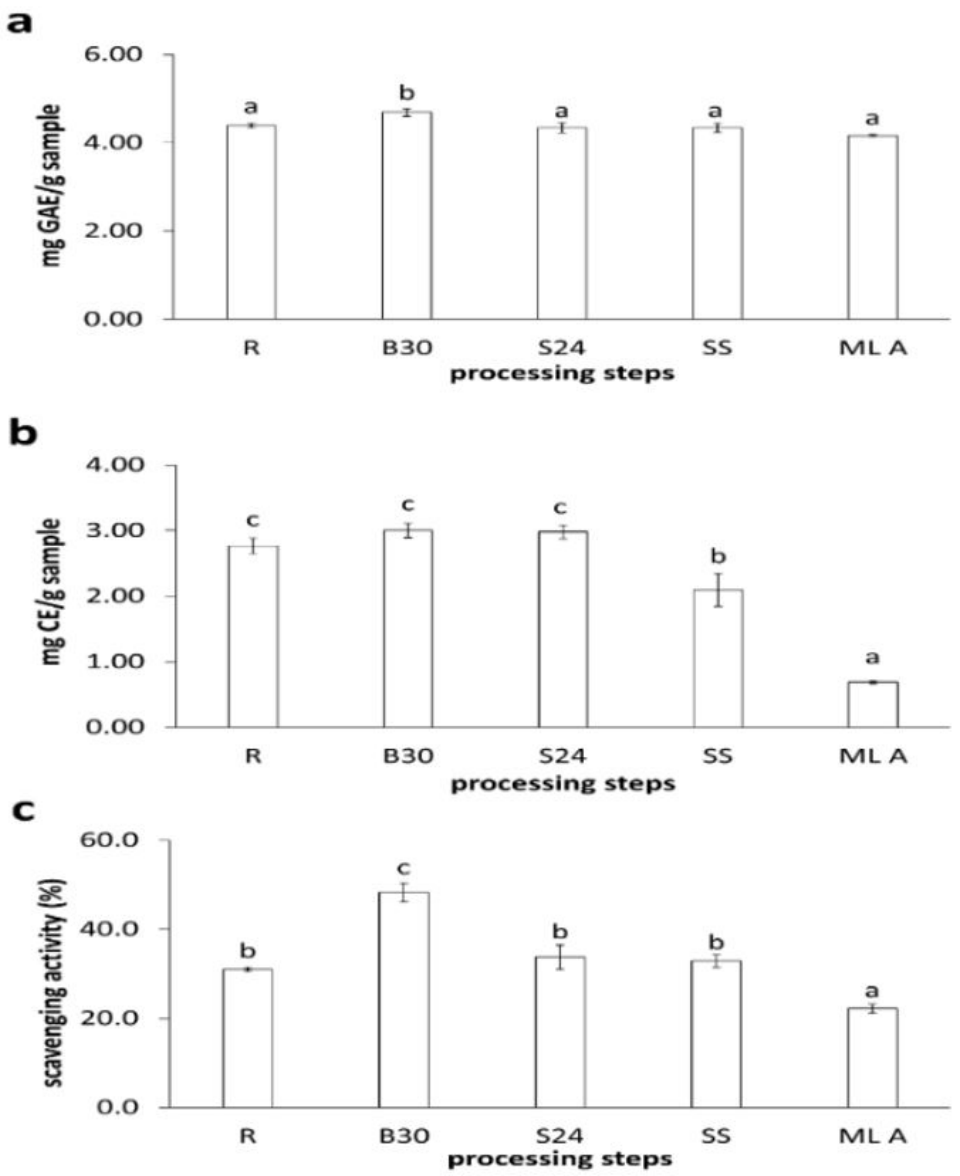

Figure 1. Total phenolic content (a), total flavonoid content (b) and DPPH free radical scavenging activity (c) of samples during jack bean milk processing steps, calculated based on dried raw beans (dry basis). R: raw bean; B30: boiling 30 min; S24: soaking 1; SS: soaking 2; MLA: jack bean milk from method A. Value ( $\mathrm{n}=3)$ followed with different letter showed statistically significant different at $p<0.05$ (Tukey's test). 
penetrated through the matrix of bean and softened the cell wall matrix, then facilitated bound phenolic to liberated therefore more extractable compounds obtained (Shahidi \& Yeo, 2016; Sowndhararajan et al., 2011).

Boiling for 30 minutes on beans (B30) gave greater TPC and TFC results $(p<0.05)$ than raw beans $(\mathrm{R})$. It is well known that some phenolics are bound to macromolecular components contained in the plant (Amoako \& Awika, 2016; Le Bourvellec \& Renard, 2012). Hydrogen bond, hydrophobic, electrostatic and ionic interaction have been reported as interaction bonds between polysaccharide and phenolics ( $\mathrm{Zhu}, 2015)$, meanwhile the interactions of phenolics to protein are mainly hydrophobic-, van der Waals-, hydrogen bond and ionic interactions (Bordenave et al., 2014). It was presumed that destruction of these bonds due to heat treatment could facilitate the release of phenolics from bean, therefore the extractable compounds in the methanol extract of boiled beans was increased (Shahidi \& Yeo, 2016; Sowndhararajan et al., 2011).

A slight decrease in TPC and TFC during soaking (S24 and SS) $(\mathrm{p}<0.05)$ could be explained by the concentrations of phenolics or flavonoids detected in boiling water and soaking water (Figures S2a, b). The stretchable structure of the seed cell not only facilitates the extraction but also provided the opportunity for flavonoid to dissolve easily, both in the boiling water during the boiling process and the soaking water during first and second soaking. Flavonoid compounds in the SS sample leached about 7.5 times higher than TFC in S24 sample explained that peeling the seed coat before the second soaking (SS) affected. Peeling the seed coat prior second soaking caused water easily penetrated and soften the structure of the seeds thus flavonoid released easier.

Antioxidant activity is one of the important characteristics of a bioactive compound. This is related to the importance of antioxidants, mainly in various degenerative diseases. Besides those consideration, the evaluation of antioxidant activity in this study also underlies the study of the potential of jack bean milk as a functional drink. The antioxidant activity was evaluated using DPPH free radical scavenging activity. The decrease pattern of changes in antioxidant activity during the jack bean milk processing was depicted in Figure 1c and gave similar profiles as TPC and TFC. It was presumed that flavonoid play the major role in antioxidant activity of this bean because the pattern of changes of DPPH free radical scavenging activity is similar to TFC.

Antioxidant activity of a phenolic compound is strongly influenced by its structure. Number and configuration of phenolic hydroxyl groups and also glycosylation and configuration of other substituents in the molecule structure of flavonoid affected its free radical scavenging activities (Cai et al., 2006; Cao et al., 1997). The presence of kaempferol in the form of glycoside also reduced kaempferol activity as an antioxidant (Heim et al., 2002). Those were in accordance with the content of the dominant polyphenolic compounds contained in jack beans which were identified as flavonoids glycosides (Sutedja et al., 2020b).

\subsection{Scanning electron microscope analysis}

Jack beans has a very hard texture, so it needs a process of softening the texture to facilitate the milk processing, by boiling the bean before soaking was applied. As mentioned above, TPC, TFC and DPPH free radical scavenging value was influenced by processing, and it was presumed that these changes were caused by alteration of bean's structural properties, such as the size and shape of starches in the bean matrix.

Changes to the bean matrix after boiling can be seen through the image of SEM shown in Figure 2. The non-smooth appearance of the starch or matrix surface (Figure $2 b$ ) explained that the matrix has expanded due to boiling water penetration into the structure. Likewise, this can be seen in a part of non-regular of raw bean flour matrix disappeared after boiling was performed (Figures $2 \mathrm{c}, \mathrm{d}$ ). It was assumed that the boiling process changes the density of the bean structure, thus helping to facilitate the access of water entering the beans at the later processing steps.

\subsection{Multivariate analysis}

Multivariate analysis on the peak intensity of detected compounds by UHPLC-MS-MS analysis was performed to evaluate the profile of compound changes during the processing of jack bean milk based on. According to the PLS-DA, the total variance was $54.2 \%$ of the data, consisting of $47.8 \%$ from component 1 and $7.4 \%$ from component 2 (Figure 3), respectively. The data showed the grouping of compounds found in each processing step from the left to the right in sequence. This explained that each stage of the milk processing has an effect on the changes of the compounds.

Evaluation of the changes during the processing was approached using variable influence on projection (VIP) values based on PLS-DA. Among top 20 features based on the VIP values, there were 12 kaempferol glycosides found as important features that changed during the milk processing according to VIP values ranged between 1.0591 to 1.608 . Seven of them were identified using the standards of kaempferol glycosides while the five of them were anisoyl kaempferol glycosides according to MS/MS analysis. Those were in accordance with the identification results of the dominant flavonoid components contained in jack beans reported in a previous study (Sutedja et al., 2020).

Production of aglycon from glycoside during food processing has been reported, although kaempferol aglycon was not observed in raw beans (Kroll et al., 2003), and it was also not found in MLA samples. This result indicated that the kaempferol glycosides were relatively stable during the jack bean milk processing. To complete the information on changes in kaempferol glycosides that changed during milk processing, a quantitative analysis was carried out to quantify kaempferol glycosides in samples from each processing step, that was discussed in the following section.

\subsection{Quantification of kaempferol glycosides}

The amount of kaempferol glycosides contained in each sample at the processing steps described a similar pattern to TPC and its antioxidant activity (Figure 2). Kaempferol glycosides were detected to be increased about $36 \%$ as the bean was boiled for $30 \mathrm{~min}$ (Table 1). The increasing of TPC and TFC from boiling sample was in line to the total 

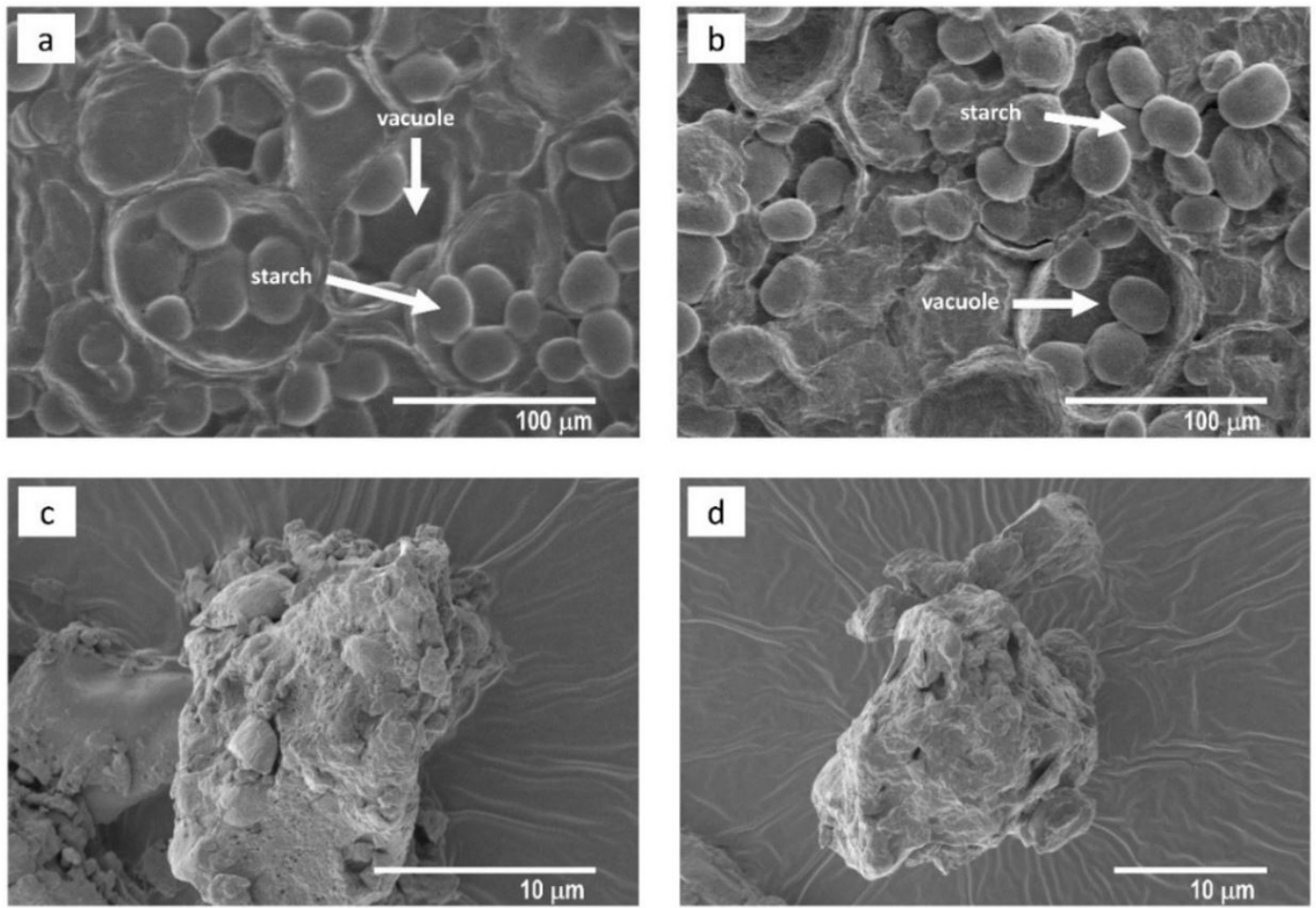

Figure 2. Scanning electron microscope of jack bean for milk processing. Raw bean seed, magnification 400× (a), 30 min boiled seed, magnification $400 \times(b)$, raw bean flour, magnification $4500 \times$ (c), 30 min boiled bean flour, magnification $3000 \times(d)$.

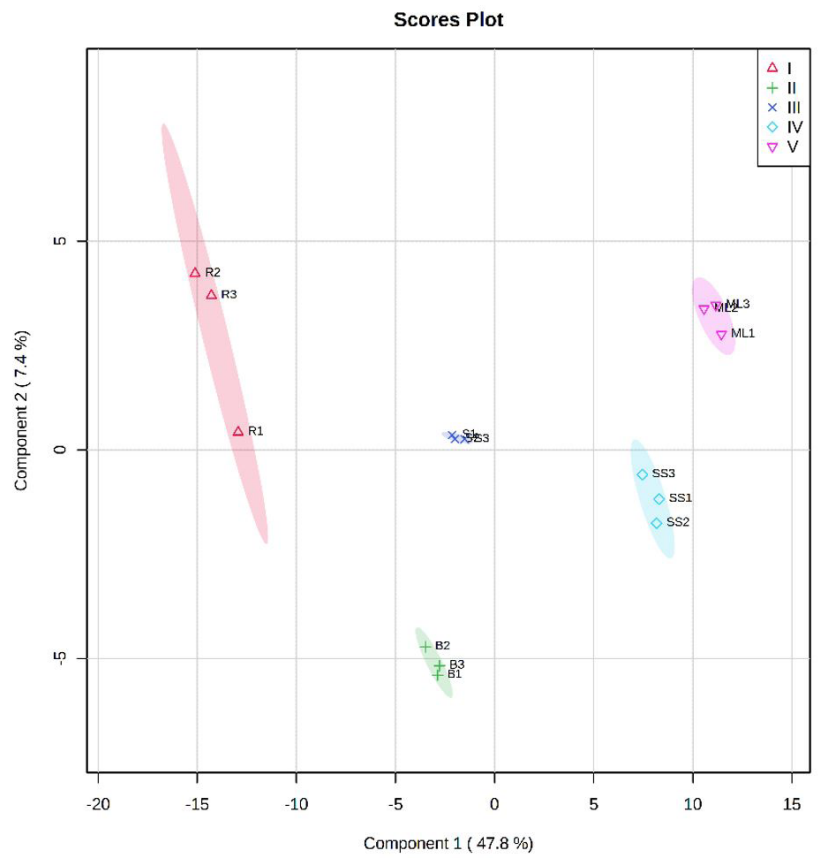

Figure 3. PLS-DA of compounds observed by UPLC-MS-MS of samples from each jack bean milk processing step. (I) R: raw bean; (II) B: bean after boiling at $30 \mathrm{~min}$; (III) S24: bean after soaking I; (IV) SS: bean after soaking II; (V) ML: bean milk.

kaempferol glycosides quantified. In present study Soaking 1 was known to reduce the amount of kaempferol glycosides in the sample by $19.3 \%$ due to the dissolution of kaempferol glycosides in the soaking water, as shown in the TPC and TFC data of soaking water (Figure S2).

There were 14 major kaempferol glycosides, and they can be classified into two groups depending on the presence or absence of anisoyl groups on the sugar moieties. Total kaempferol glycoside content in raw bean was $1122.4 \mu \mathrm{g} / \mathrm{g}$, consisted $46 \%$ anisoyl kaempferol glycosides. Non-anisoyl kaempferol glycosides increased about $42 \%$ during boiling for 30 minutes, meanwhile the increase of anisoyl kaempferol glycosides about $28 \%$. On the other hand, kaempferol glycosides were observed to be decreased during soaking, described by the loss of these compounds into the soaking water. The percentage reduction of non-anisoyl kaempferol glycosides was 1.4 times greater than anisoyl kaempferol glycoside which explained that this compound was unstable during milk processing. Non-anisoyl kaempferol glycosides with higher polarity tended to leach easier than anisoyl type.

\subsection{Variation of processing procedures on the functional characteristics of jack bean milk}

To investigate the influence of soaking step variation, three milk products prepared by method $\mathrm{A}, \mathrm{B}$ and $\mathrm{C}$ were compared (Figure 4). TFC in MLB and MLC, which had reducing soaking time (step 2) and eliminating soaking 2 (step 3), were significantly higher than MLA. Considering TFC data of MLB in accordance with the total amount of kaempferol glycosides in MLB higher than MLA and MLC (Table 1) explained the modification of the process by eliminating soaking 2 (step 3 ) in MLB affected the functional properties, especially through the changes of flavonoid content. 
Table 1. Concentration $(\mu \mathrm{g} / \mathrm{g})$ of main phenolics in methanol extracts of dried samples obtained from jack bean milk processing*.

\begin{tabular}{|c|c|c|c|c|c|c|c|c|c|}
\hline \multirow{2}{*}{ Compounds } & \multirow{2}{*}{$\begin{array}{l}\mathrm{RT}^{* *} \\
(\mathrm{~min})\end{array}$} & \multirow{2}{*}[\mathrm{M}+\mathrm{H}]{$^{+* *}$} & \multicolumn{7}{|c|}{ Concentration $(\mu \mathrm{g} / \mathrm{g})$ of main phenolics in methanol extracts of dried samples } \\
\hline & & & $\mathrm{R}$ & B30 & S24 & SS & MLA & MLB & MLC \\
\hline $\begin{array}{l}\text { Kaempferol } \\
\text { tetraglycoside (I) }\end{array}$ & 18.0 & 903 & $90.26 \pm 0.83$ & $124.14 \pm 1.30$ & $64.09 \pm 0.14$ & $77.02 \pm 1.49$ & $60.64 \pm 0.59$ & $60.70 \pm 0.70$ & $62.95 \pm 0.18$ \\
\hline $\begin{array}{l}\text { Kaempferol 3-O- } \alpha \text { - } \\
\text { L-rhamnopyranosyl } \\
(1 \rightarrow 2)[\alpha-L- \\
\text { rhamnopyranosyl } \\
(1 \rightarrow 6)]-\beta-d- \\
\text { glucopyranoside- } \\
\text { 7-O- } \alpha \text {-L- } \\
\text { rhamnopyranoside }\end{array}$ & 19.6 & 887 & $172.67 \pm 0.97$ & $329.78 \pm 8.16$ & $183.77 \pm 9.60$ & $173.18 \pm 4.77$ & $90.62 \pm 1.24$ & $135.32 \pm 1.19$ & $125.49 \pm 0.97$ \\
\hline $\begin{array}{l}\text { Kaempferol } \\
\text { tetraglycoside (II) }\end{array}$ & 25.8 & 873 & $60.53 \pm 0.26$ & $62.20 \pm 0.12$ & $61.91 \pm 0.25$ & $65.31 \pm 0.17$ & $60.80 \pm 0.19$ & $58.74 \pm 0.77$ & $61.82 \pm 0.19$ \\
\hline $\begin{array}{l}\text { Kaempferol } \\
\text { triglycoside (I) }\end{array}$ & 26.9 & 757 & $51.88 \pm 0.16$ & $58.91 \pm 0.70$ & $69.43 \pm 1.06$ & $70.25 \pm 0.63$ & $58.25 \pm 0.14$ & $50.86 \pm 0.55$ & $51.40 \pm 0.09$ \\
\hline $\begin{array}{l}\text { Kaempferol } \\
\text { triglycoside (II) }\end{array}$ & 30.0 & 741 & $50.40 \pm 0.07$ & $50.02 \pm 0.48$ & $50.46 \pm 0.05$ & $49.75 \pm 0.49$ & $49.83 \pm 0.62$ & $49.77 \pm 0.51$ & $50.08 \pm 0.55$ \\
\hline $\begin{array}{l}\text { Kaempferol } \\
3 \text {-O-(2,6-di- } \alpha \text {-L- } \\
\text { rhamnopyranosyl)- } \\
\beta \text {-glucopyranoside }\end{array}$ & 31.1 & 741 & $88.47 \pm 1.26$ & $138.00 \pm 3.09$ & $122.26 \pm 0.89$ & $119.61 \pm 1.19$ & $75.93 \pm 1.32$ & $95.99 \pm 1.29$ & $85.49 \pm 1.14$ \\
\hline $\begin{array}{l}\text { Kaempferol } \\
\text { triglycoside (III) }\end{array}$ & 33.4 & 727 & $50.47 \pm 0.05$ & $49.42 \pm 0.09$ & $50.20 \pm 0.13$ & $67.66 \pm 0.32$ & $49.59 \pm 0.07$ & $49.90 \pm 0.13$ & $56.74 \pm 0.73$ \\
\hline $\begin{array}{l}\text { Kaempferol } \\
\text { diglycoside }\end{array}$ & 34.4 & 595 & $44.35 \pm 0.07$ & $54.02 \pm 0.90$ & $54.69 \pm 0.78$ & $40.68 \pm 0.12$ & $46.50 \pm 0.74$ & $48.58 \pm 0.45$ & $40.88 \pm 0.05$ \\
\hline $\begin{array}{l}\text { Kaempferol 3-O- } \alpha \text { - } \\
\text { L-rhamnopyranosyl } \\
(1 \rightarrow 6)-\beta \text {-D- } \\
\text { glucopyranosyl } \\
(1 \rightarrow 2)-\beta \text {-d- } \\
\text { galactopyranosyl- } \\
\text { 7-O-[3-O-o- } \\
\text { anisoyl]- } \alpha \text {-L- } \\
\text { rhamnopyranoside }\end{array}$ & 48.0 & 1037 & $98.33 \pm 1.02$ & $131.85 \pm 0.77$ & $105.81 \pm 0.84$ & $105.25 \pm 1.25$ & $81.96 \pm 0.75$ & $94.13 \pm 1.14$ & $94.50 \pm 1.84$ \\
\hline $\begin{array}{l}\text { Anisoyl kaempferol } \\
\text { tetraglycoside (I) }\end{array}$ & 49.0 & 1037 & $89.36 \pm 0.72$ & $124.26 \pm 1.51$ & $106.12 \pm 2.03$ & $112.01 \pm 1.09$ & $78.59 \pm 0.19$ & $89.32 \pm 1.21$ & $83.73 \pm 0.79$ \\
\hline $\begin{array}{l}\text { Kaempferol } \\
3-\mathrm{O}-(2,6-\mathrm{di}-\alpha-\mathrm{L}- \\
\text { rhamnopyranosyl)- } \\
\beta \text {-D- } \\
\text { galactopyranoside- } \\
\text { 7-O-[3-O-o- } \\
\text { anisoyl]- } \alpha-\mathrm{L}- \\
\text { rhamnopyranoside }\end{array}$ & 49.3 & 1021 & $90.57 \pm 0.76$ & $117.55 \pm 0.32$ & $99.77 \pm 1.09$ & $98.90 \pm 1.24$ & $78.79 \pm 0.17$ & $87.26 \pm 0.92$ & $83.36 \pm 1.28$ \\
\hline $\begin{array}{l}\text { Anisoyl kaempferol } \\
\text { tetraglycoside (II) }\end{array}$ & 50.2 & 1021 & $88.71 \pm 0.81$ & $120.49 \pm 0.94$ & $102.98 \pm 1.30$ & $102.03 \pm 0.71$ & $76.17 \pm 0.24$ & $82.40 \pm 1.25$ & $80.23 \pm 1.39$ \\
\hline $\begin{array}{l}\text { Anisoyl kaempferol } \\
\text { tetraglycoside (III) }\end{array}$ & 51.8 & 1037 & $74.55 \pm 0.24$ & $84.52 \pm 1.51$ & $80.19 \pm 0.22$ & $81.60 \pm 0.99$ & $77.40 \pm 0.21$ & $82.61 \pm 1.34$ & $79.07 \pm 0.23$ \\
\hline $\begin{array}{l}\text { Anisoyl kaempferol } \\
\text { tetraglycoside (IV) }\end{array}$ & 52.4 & 1021 & $71.86 \pm 0.15$ & $80.42 \pm 0.63$ & $78.87 \pm 0.23$ & $77.99 \pm 0.24$ & $76.46 \pm 0.31$ & $78.08 \pm 0.24$ & $75.91 \pm 0.18$ \\
\hline Total & & & $1,122.41$ & $1,525.60$ & $1,230.53$ & $1,241.24$ & 961.51 & $1,063.65$ & $1,031.64$ \\
\hline
\end{tabular}

${ }^{*}$ All extracts were obtained from the same volume of methanol used for extraction of based on $50 \mathrm{~g}$ dried beans $(1: 10 \mathrm{w} / \mathrm{v})$. All concentrations were determined using kaempferol as a standard and based on a calibration curve $\left(5 \times 10^{-4}-1 \mathrm{mg} / \mathrm{mL}\right)$ of the standard. ${ }^{* *} \mathrm{RT}=$ retention time; $[\mathrm{M}+\mathrm{H}]^{+}=$mass number of molecular ions adducted by protons.

The total amount of kaempferol glycosides during the manufacture of MLB decreased by $5 \%$ explained that the product still contained the compounds in quantities similar to those in the raw bean. Specifically, the finding that the total anisoyl kaempferol glycosides known to be equal to those in the raw beans supports this product to become a functional product.
In previous study, kaempferol glycosides with an anisoyl group exhibited a-glucosidase inhibitory activity competitive with acarbose (Sutedja et al., 2020b). Thus, this result suggested that this milk product can potentially become a new alternative functional drink specifically for diabetics. Evaluation of product characteristics also needs to be studied further from 

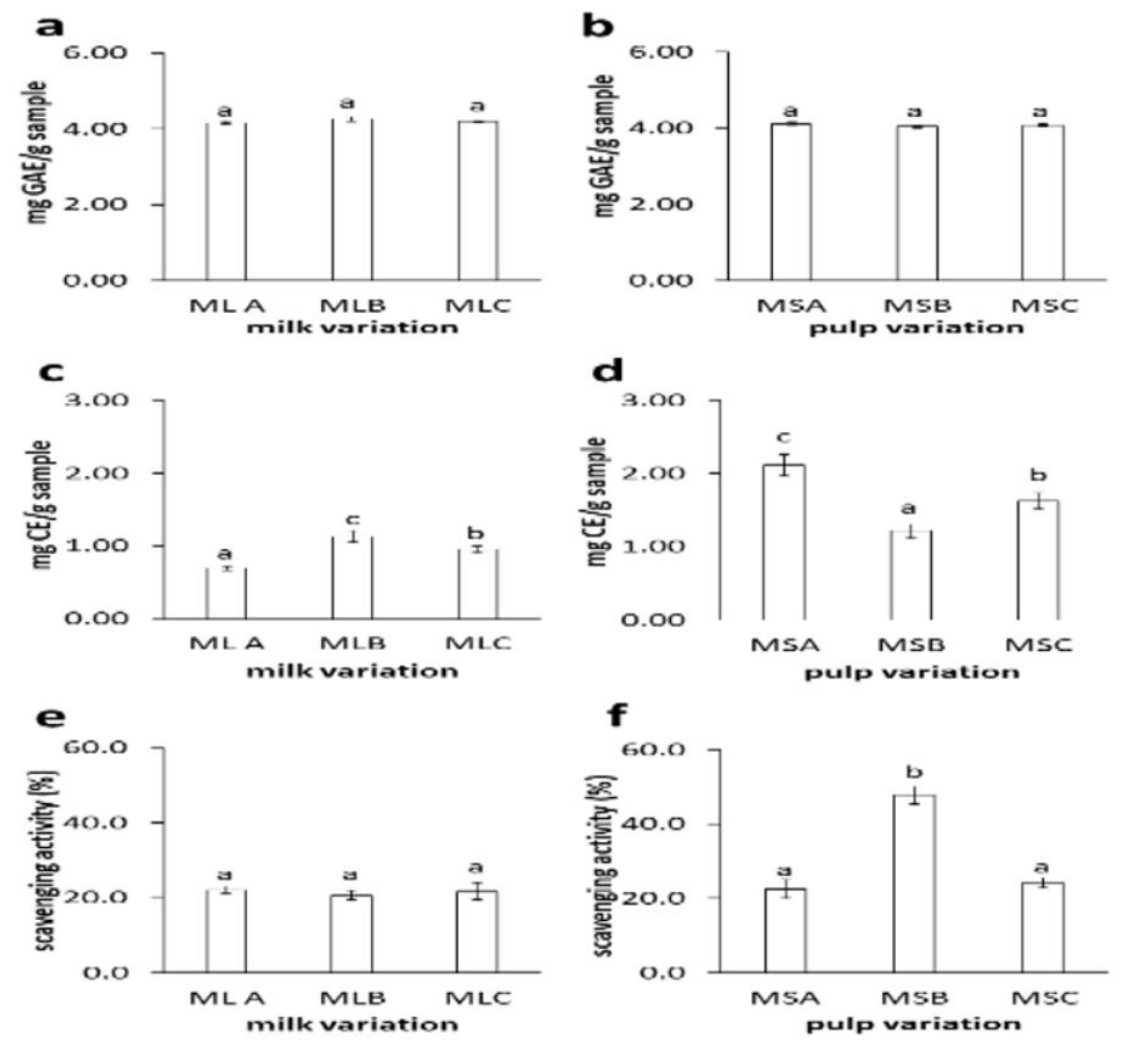

Figure 4. TPC (mg GAE/g sample), TFC (mg CE/g sample) and DPPH free radical scavenging activity of jack bean milks (a, c, and e) and pulps $(b, d$ and $\mathrm{f}$ ) from various processing methods. Values $(\mathrm{n}=3)$ followed with different letters showed statistically significant different at $p<0.05$ (Tukey's test).

its physicochemical and sensory aspects so that at the end a functional drink with a good product quality can be obtained.

Sensory evaluation analysis is very necessary to know the sensory characteristics of the jack bean milk. There are some innovative methods based on consumer perception that can be used for this purpose. Quantitative descriptive analysis (QDA) and temporal dominance of sensations (TDS) are conveyed to be an important tool in product development (Silva et al., 2018). Both of these methods will help define the sensory components profile of the jack bean milk. Sensory analysis using the word association method (Judacewski et al., 2019) and descriptive sensory analysis (DSA) (Cais-Sokolińska et al., 2021) can help describe the dominant sensory characteristics of this products. Known the sensory characteristics of jack bean milk products will support the efforts that can be made to improve the sensory characteristics of the jack bean milk. Thus, this sensory analysis will be the next plan for further research in an effort to produce functional beverage products with a good level of consumer acceptance.

In particular, when reviewing the pulp from milk processing variations, the three types of pulp still contained the polyphenol compounds, especially flavonoids, which were almost equivalent to their content in milk. This compound seemed to partially retained in the fiber fraction (Giri \& Mangaraj, 2012). These data indicated the potential of the pulp to be further utilized, similar to "okara" as a by-product of processing soybean milk. The opportunities to utilize pulp as a byproduct of jack bean milk processing, explained that the processing could give a reduced waste.

\section{Conclusion}

Processing of jack bean into plant-based milk was one of the efforts to diversify food products, especially to provide functional foods that were easily produced. TPC, TFC and DPPH free radical scavenging activity were reduced during the milk processing, likewise kaempferol glucosides. The soaking step played a major role in determining the changes of flavonoid contents in jack bean milk. Soaking the beans before peeling provided the highest flavonoid content in this study.

UHPLC-MS-MS based multivariate analysis described kaempferol glycosides as the main compounds to change during milk processing. Non-anisoyl kaempferol glycosides tended to be unstable during processing compared to anisoyl kaempferol glycosides. Although loss of the kaempferol glycosides were observed, it was known that the anisoyl kaempferol glycosides available in similar quantities with those of raw beans. This could provide an added value to the jack beans when they are processed into a functional drink.

\section{References}

Ade-Omowaye, B. I. O., Tucker, G. A., \& Smetanska, I. (2015). Nutritional potential of nine underexploited legumes in Southwest Nigeria. International Food Research Journal, 22(2), 798-806. 
Al-Juhaimi, F., Ghafoor, K., Özcan, M. M., Jahurul, M. H. A., Babiker, E. E., Jinap, S., Sahena, F., Sharifudin, M. S., \& Zaidul, I. S. M. (2018). Effect of various food processing and handling methods on preservation of natural antioxidants in fruits and vegetables. Journal of Food Science and Technology, 55(10), 3872-3880. http://dx.doi. org/10.1007/s13197-018-3370-0. PMid:30228385.

Amoako, D., \& Awika, J. M. (2016). Polyphenol interaction with food carbohydrates and consequences on availability of dietary glucose. Current Opinion in Food Science, 8, 14-18. http://dx.doi.org/10.1016/j. cofs.2016.01.010.

Bakowska, A., Kucharska, A. Z., \& Oszmiański, J. (2003). The effects of heating, UV irradiation, and storage on stability of the anthocyaninpolyphenol copigment complex. Food Chemistry, 81(3), 349-355. http://dx.doi.org/10.1016/S0308-8146(02)00429-6.

Bordenave, N., Hamaker, B. R., \& Ferruzzi, M. G. (2014). Nature and consequences of non-covalent interactions between flavonoids and macronutrients in foods. Food \& Function, 5(1), 18-34. http://dx.doi. org/10.1039/C3FO60263J. PMid:24326533.

Cai, Y.-Z., Mei Sun, Jie Xing, Luo, Q., \& Corke, H. (2006). Structureradical scavenging activity relationships of phenolic compounds from traditional Chinese medicinal plants. Life Sciences, 78(25), 28722888. http://dx.doi.org/10.1016/j.lfs.2005.11.004. PMid:16325868.

Cais-Sokolińska, D., Kaczyński, Ł. K., Bierzuńska, P., Skotarczak, E., \& Dobek, A. (2021). Consumer acceptance in context: Texture, melting, and sensory properties of fried ripened curd cheese. International Journal of Dairy Technology, 74(1), 225-234. http:// dx.doi.org/10.1111/1471-0307.12747.

Cao, G., Sofic, E., \& Prior, R. L. (1997). Antioxidant and prooxidant behavior of flavonoids: structure-activity relationships. Free Radical Biology \& Medicine, 22(5), 749-760. http://dx.doi.org/10.1016/ S0891-5849(96)00351-6. PMid:9119242.

Chong, J., Wishart, D. S., \& Xia, J. (2019). Using MetaboAnalyst 4.0 for comprehensive and integrative metabolomics data analysis. Current Protocols in Bioinformatics, 68(1), e86. http://dx.doi.org/10.1002/ cpbi.86. PMid:31756036.

Doss, A., Pugalenthi, M., \& Vadivel, V. (2011). Nutritional evaluation of wild jack bean (Canavalia ensiformis DC) seeds in different locations of South India. World Applied Sciences Journal, 13(7), 1606-1612.

Giri, S. K., \& Mangaraj, S. (2012). Processing influences on composition and quality attributes of soymilk and its powder. Food Engineering Reviews, 4(3), 149-164. http://dx.doi.org/10.1007/s12393-012-9053-0.

Hammer, Ø., Harper, D. A. T., \& Ryan, P. D. (2001). Past: paleontological statistics software package for education and data analysis. Palaeontologia Electronica, 4(1), 1-9.

Heim, K. E., Tagliaferro, A. R., \& Bobilya, D. J. (2002). Flavonoid antioxidants: chemistry, metabolism and structure-activity relationships. The Journal of Nutritional Biochemistry, 13(10), 572-584. http://dx.doi. org/10.1016/S0955-2863(02)00208-5. PMid:12550068.

Huang, H., Liang, H., \& Kwok, K.-C. (2006). Effect of thermal processing on genistein, daidzein and glycitein content in soymilk. Journal of the Science of Food and Agriculture, 86(7), 1110-1114. http://dx.doi. org/10.1002/jsfa.2465.

Judacewski, P., Los, P. R., Lima, L. S., Alberti, A., Zielinski, A. A. F., \& Nogueira, A. (2019). Perceptions of Brazilian consumers regarding white mould surface-ripened cheese using free word association. International Journal of Dairy Technology, 72(4), 585-590. http:// dx.doi.org/10.1111/1471-0307.12649.

Kroll, J., Rawel, H. M., \& Rohn, S. (2003). Reactions of plant phenolics with food proteins and enzymes under special consideration of covalent bonds. Food Science and Technology Research, 9(3), 205218. http://dx.doi.org/10.3136/fstr.9.205.

Le Bourvellec, C., \& Renard, C. M. G. C. (2012). Interactions between polyphenols and macromolecules: quantification methods and mechanisms. Critical Reviews in Food Science and Nutrition, 52(3), 213248. http://dx.doi.org/10.1080/10408398.2010.499808. PMid:22214442.

Niyibituronsa, M., Onyango, A. N., Gaidashova, S., Imathiu, S., Uwizerwa, M., Ochieng, E. P., Ng'ang'a, F., Birungi, J., Ghimire, S., \& Harvey, J. (2018). The effect of different processing methods on nutrient and isoflavone content of soymilk obtained from six varieties of soybean grown in Rwanda. Food Science \& Nutrition, 7(2), 457-464. http:// dx.doi.org/10.1002/fsn3.812. PMid:30847123.

Olugboyega, S. K., \& Edem, A. R. (2018). Comparative phytochemicals and in vitro antioxidative effects of jack beans (Canavalia ensiformis) and sword beans (Canavalia gladiata). Annals. Food Science and Technology (Valahia University of Târgoviste), 19, 499-505.

Sethi, S., Tyagi, S. K., \& Anurag, R. K. (2016). Plant-based milk alternatives an emerging segment of functional beverages: A review. Journal of Food Science and Technology, 53(9), 3408-3423. http://dx.doi. org/10.1007/s13197-016-2328-3. PMid:27777447.

Shahidi, F., \& Yeo, J. (2016). Insoluble-bound phenolics in food. Molecules, 21(9), 1216. http://dx.doi.org/10.3390/molecules21091216. PMid:27626402.

Silva, H. L. A., Balthazar, C. F., Silva, R., Vieira, A. H., Costa, R. G. B., Esmerino, E. A., Freitas, M. Q., \& Cruz, A. G. (2018). Sodium reduction and flavor enhancer addition in probiotic prato cheese: contributions of quantitative descriptive analysis and temporal dominance of sensations for sensory profiling. Journal of Dairy Science, 101(10), 8837-8846. http://dx.doi.org/10.3168/jds.2018-14819. PMid:30077456.

Sowndhararajan, K., Siddhuraju, P., \& Manian, S. (2011). Antioxidant activity of the differentially processed seeds of jack bean (Canavalia ensiformis L. DC). Food Science and Biotechnology, 20(3), 585-591. http://dx.doi.org/10.1007/s10068-011-0083-9.

Sutedja, A. M., Fardiaz, D., Batubara, I., Lioe, H. N., Mitsunaga, T., Syah, D., \& Yanase, E. (2020a). Potency of jack bean (Canavalia ensiformis (L.) DC) and red kidney bean (Phaseolus vulgaris L.) extracts as antidiabetic agents. Journal of Food Agriculture and Environment, 18(3 \& 4), 36-42.

Sutedja, A. M., Yanase, E., Batubara, I., Fardiaz, D., \& Lioe, H. N. (2020b). Identification and characterization of $\alpha$-glucosidase inhibition flavonol glycosides from jack bean (Canavalia ensiformis (L.) DC. Molecules, 25(11), 2481. http://dx.doi.org/10.3390/molecules25112481. PMid:32471071.

Tangyu, M., Muller, J., Bolten, C. J., \& Wittmann, C. (2019). Fermentation of plant-based milk alternatives for improved flavour and nutritional value. Applied Microbiology and Biotechnology, 103(23-24), 9263-9275. http://dx.doi.org/10.1007/s00253-019-10175-9. PMid:31686143.

Vadivel, V., Cheong, J. N., \& Biesalski, H. K. (2012). Antioxidant and type II diabetes related enzyme inhibition properties of methanolic extract of an underutilized food legume, Canavalia ensiformis (L.) DC: Effect of traditional processing methods. LWT, 47(2), 255-260. https://doi.org/10.1016/j.lwt.2012.01.014.

Volf, I., Ignat, I., Neamtu, M., \& Popa, V. (2014). Thermal stability, antioxidant activity, and photo-oxidation of natural polyphenols. Chemical Papers, 68(1). http://dx.doi.org/10.2478/s11696-013-0417-6.

Zhang, Y., Chang, S. K. C., \& Liu, Z. (2015). Isoflavone profile in soymilk as affected by soybean vriety, grinding, and heat-processing methods: grinding and heat-processing methods. Journal of Food Science, 80(5), C983-C988. http://dx.doi.org/10.1111/1750-3841.12839. PMid:25827234.

Zhu, F. (2015). Interactions between starch and phenolic compound. Trends in Food Science \& Technology, 43(2), 129-143. http://dx.doi. org/10.1016/j.tifs.2015.02.003. 


\section{Supplementary Material}

Supplementary material accompanies this paper.

Figure S1. Milk processing variation used in this study.

Figure S2. Total phenolic content (a), total flavonoid content (b) and DPPH scavenging activity (c) of boiling water and soaking water from jack bean milk processing. BW: boiling water from boiling $30 \mathrm{~min}$; SW: soaking water from soaking 1 (24 h); SW2: soaking water from soaking 2 (50 min).

This material is available as part of the online article from http://www.scielo.br/cta 